\title{
Obraz śmierci w kazaniach z czasów Księstwa Warszawskiego
}

Monika Hamanowa 
nAP7S Seria V 1999

\section{Monika Hamanowa}

\section{Obraz śmierci w kazaniach z czasów Księstwa Warszawskiego}

W skromnej liczbie publikacji, jakie ukazały się w latach istnienia Księstwa Warszawskiego, dość znaczna jest proporcja wydanych drukiem kazań. Są to albo wygłoszone z różnych okazji pojedyncze kazania, które ich autorzy uznali za godne druku, albo zbiory kazań. Te ostatnie zawierają kazania rzeczywiście wygłoszone oraz takie, które napisane zostały tylko po to, by służyć jako wzór lub źródło inspiracji mniej elokwentnym proboszczom czy wikarym. W niektórych zbiorach znajduje się oba rodzaje tych tekstów. Wśród jednych i drugich problem śmierci zajmuje poczesne miejsce, dotyczy to zwłaszcza kazań wygłaszanych podczas mszy żałobnych i w Dniu Zadusznym. Trudno byłoby się temu dziwić — ówczesna wysoka śmiertelność, na którą nakładały się jeszcze straty wojenne, sprawiała, że śmierć byla wszechobecnym, codziennym niemal elementem ludzkiego życia.

W Krakowie w 1806 r. ukazała się książeczka pod przydługim tytułem Nauka praktyczna dla pasterzów dusz ludzkich, podlug której postępować maja z chorymi umierajacymi $i$ na śmieŕ publiczna wyrokiem sprawiedliwości wskazanymi. Było to dokonane przez Innocentego Konczewicza polskie tłumaczenie wydanego piętnaście lat wcześniej w Moguncji dziełka księdza G. Koehlera, profesora teologii tamż ${ }^{\hat{1}}$. Przynosząc rady dla księży, udzielających ostatniej pociechy, książeczka ta wywarła, jak sądzić można, pewien wpływ na treść kazań podejmujących problem śmierci.

Rady te dają się sprowadzić do zalecenia, aby kierować się w każdych okolicznościach troską o zbawienie wieczne dusz ludzi, odchodzących z tego świata. Tak więc ksiądz wezwany do loża ciężko chorego powinien nakłonić go do przyjęcia ostatnich sakramentów nawet

\footnotetext{
1 Imię autora: Gregor lub Georg; zob. K. Estreicher, Bibliografia polska XIX stulecia, t. 2, Kraków 1874, s. 401: „Koehler Grzegorz (Jerzy?)”.
} 
wówczas, gdyby miało to spowodować niepokój chorego, a tym samym przyspieszyć jego śmierć. Chorym, którzy boją się śmierci, należy przedstawiać ją jako radosny moment triumfu. Czyż można bowiem wierzyć w szczęśliwość wieczną i obawiać się wiodącej do niej drogi, prosić Boga co dzień o nadejście Jego Królestwa i drżeć, gdy się zbliża?

Przy skomplikowanych porodach ksiądz powinien nalegać na rodzące, by nie bacząc na swe własne zdrowie poddały się operacji cesarskiego cięcia po to, by dziecię ich nie zmarło bez chrztu. A jeśli kobieta zmarłaby w czasie porodu, zanim dziecko przyszło na świat, powinno się dokonać cięcia i wydobyć je z łona matki, by je ochrzcić, nawet warunkowo, w razie gdyby nie dawało oznak życia. Autor posunął się wręcz do tego, by zalecać księżom nauczenia się na wszelki wypadek wykonywania takiej operacji ${ }^{2}$.

Ksiądz asystujący skazanemu na śmierć powinien przekonywać go, by nie buntował się przeciwko orzeczonej nań karze, lecz przyznał, że na nią zasłużył przez złe uczynki, i wyraził skruchę. Szczera skrucha skazańca jest budującym przykładem dla wszystkich grzeszników i może zawrócić ich ze złej drogi. Jeśli zaś egzekucja jest publiczna, ksiądz może przemówić do zgromadzonego tłumu, a pod wpływem widoku okropnej kaźni słowa jego moga sprawić wiele dobrego.

Problemowi śmierci poświęcony jest w dużej mierze drugi tom kazań krakowskiego franciszkanina Józefa Męcińskiego ${ }^{3}$. Wiedząc z doświadczenia - o czym pisał we wstępie jak trudno w krótkim czasie przychodzi kaznodziejom przygotować potrzebną mowę, opracował on wzory kazań pogrzebowych na różne okoliczności. Znajdujemy więc w tym tomie kazanie na pogrzebie kapłana, młodzieńca, młodej panienki, „białogłowy szlachetnej w średnim wieku zmarłej", obywatela i wdowy w wieku podeszłym, nawróconego libertyna i nawróconego heretyka, osoby zmarłej nagłą śmiercią, a także zmarłego lekarza lub aptekarza. Różnice stanowe odzywały się echem we wzorach kazań na pogrzebie zmarłego wieśniaka lub ubogiego żebraka, który „umiera wesoło, nie doznając goryczy umierającego bogacza” 4 . Kazania wygłoszone na pogrzebach lub w rocznicę śmierci, a następnie ogłoszone drukiem, dotyczyły z reguły zmarłych pochodzących z wyższych klas społecznych. Uważano zapewne, że tylko one warte są rozpowszechnienia.

Bez względu na to, czy mamy do czynienia z wzorami kazań, czy z konkretnymi kazaniami, we wszystkich wyraża się ta sama postawa wobec śmierci. Autorów kazań nie interesuje śmierć sama w sobie. Nie zadają sobie pytania, czy należy ją traktować jako zjawisko natural-

\footnotetext{
2 Podany jest nawet opis, jak należy ją wykonać: „Wziąwszy dobry nożyk, którym się pióra temperuje...”, s. 128.

${ }^{3}$ J. Męciński, Moư kaznodziejskie w różnych nabożeństu'a (osobliwie parafialnego) okolicznościach..., t. 2, Kraków 1808.

${ }^{4} \mathrm{~W}$ innych przejrzanych przeze mnie zbiorach kazań temat śmierci był tylko jednym z podejmowanych problemów. Szczególnie interesujące jest dzieło Filipa Neriusza Golańskiego, pijara, profesora teologii Uniwersytetu Wileńskiego Materiat kaznodziejski dla pomocy zbawiennego opowiadania Stowa Bożego..., Wilno 1813. Kilka tomów kazań opublikowanych przez kaznodzieję przemyskiego, franciszkanina Konrada Kawalewskiego stanowi ciekawe źródło dla historii mentalności ze względu na prezentowane w nich ludowe podejście do wiary chrześcijańskiej.
} 
ne, część normalnego rytmu ludzkiej egzystencji, czy też jako zesłaną przez Boga karę za ludzkie grzechy. Widzą w niej raczej furtkę, przez którą ludzie cnotliwi przechodzą do życia wiecznego i wiecznej szczęśliwości. Wspominają o starości, lecz milczą na temat innych kategorii osób, nie mniej niż starcy zagrożonych rychłą śmiercią, a mianowicie żołnierzy i kobiet w wieku prokreacji. Postawa kaznodziejów wydaje się czysto instrumentalna i pedagogiczna. Nie na darmo Józef Męciński we wstępie do drugiego tomu swych Mów kaznodziejskich stwierdzał, że "mowy na pogrzebach nad zwłokami i grobami umarłych nie są tylko dla nich umarłych, ale i dla żyjących przestrogi, nauki życia i śmierci”. Cele takich kazań jasno określił biskup Adam Prażmowski w kazaniu wygłoszonym w Warszawie w 1815 r. na pogrzebie Anny Pociejowej: śmierć tej młodej jeszcze, zaledwie 35-letniej kobiety powinna po pierwsze „zwrócić myśli nasze na prawidła chrześcijańskiego życia”, po wtóre „zgon jej

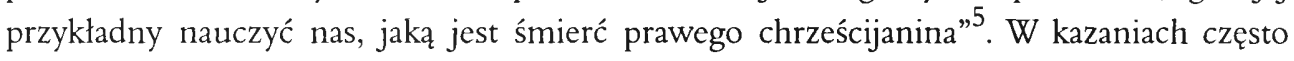
napominano rodzinę i bliskich zmarłego, by nie pogrążali się w nadmiernej rozpaczy, niegodnej chrześcijanina.

Ksiądz Filip Neriusz Golański przestrzegał, że kazanie na pogrzebie jest wprawdzie mową pochwalną, lecz pochwały zmarłego muszą być zasłużone, a nawet należy dawkować je oszczędnie. Przykład czlowieka wolnego od wad, słabości i omyłek byłby dla żyjących nieużyteczny, bowiem niedościgły, natomiast z omyłek nieboszczyka żyjący czerpać mogą przestrogi. Kaznodzieja powinien wskazywać, jak zmarły dobrymi uczynkami i cnotą odkupywał swoje słabości i błędy ${ }^{6}$. W praktyce jednak kaznodzieje przeważnie ograniczali się do pochwał, nie uniknął tego i sam ks. Golański. W kazaniu na żałobnym nabożeństwie za duszę Tadeusza Czackiego powtarzał wprawdzie, że „i z omyłek chwalebnych ludzi miewamy dla siebie przestroge", lecz jedyny zarzut, jaki stawia zmarłemu, to zbytnie skoncentrowanie się na sprawach Liceum Krzemienieckiego ${ }^{7}$.

Z kazań wygłaszanych na pogrzebach osób stanu szlacheckiego, wyższych urzędników, księży i uczonych wyłaniają się stereotypy tworzące wzorce przykładnego życia. Uderza ich jednostajność, zwłaszcza w odniesieniu do kobiet. Nieboszczki pochodziły z reguły z dobrych, jeśli nie znakomitych, rodzin, a ich wychowanie nacechowane było pobożnością. Jako małżonki posłuszne i wierne wspomagały swych mężów i służyły im pociechą w strapieniach, jako wzorowe i oddane matki wychowywały swe potomstwo w wierze katolickiej. Dobre gospodynie, dbały o porządek i oszczędność, służbę i domowników traktowały łagodnie i sprawiedliwie. Ich stosunek do sąsiadów charakteryzowała dyskrecja i uczynność. Szanowały księży i były hojne dla Kościoła. Cierpliwie znosiły choroby i cierpienia. Dwie cechy natomiast nader rzadko są wspominane w kazaniach wygłaszanych na pogrzebach tych

\footnotetext{
5 [A. M. ] Prażmowski, Kazanie na obchodzie pogrzebowym Anny z Korzeniowskich hrabiny Pociejowej oboźnej W. Ks. Litewskiego, zmartej 12 maja, miane w kościele warszawskim OO. Kapucynów 10 czerwca 1815 ... [b. m. r. dr.]. ${ }^{6}$ F. N. Golański, Materiat kaznodziejski..., op. cit., s. 348.

7 Zob. tenże, Kazanie przy uroczystym obchodzie żalobnego nabożeństwa za duszę śp. Tadeusza Czackiego... w kościele akademickim św. Jana 20 marca roku bieżqcego..., Wilno 1813.
} 
niewiast, a mianowicie patriotyzm i dobroczynność. Prawie nigdy zaś nie mówi się o ich wykształceniu i talentach ${ }^{8}$.

Mężczyźni również pochodzą z dobrych rodzin, są dobrymi katolikami, wiernymi i kochającymi mężami, sumiennymi ojcami, szczerymi przyjaciółmi, uczynnymi sąsiadami, łagodnymi i sprawiedliwymi panami, dobroczyńcami ubogich, opiekunami sierot, hojnymi dla Kościoła i pełnymi uszanowania wobec jego sług. Wzorce osobowe są jednak w ich wypadku bardziej urozmaicone, ponieważ bierze się pod uwagę zawód, jaki wykonywali w życiu. Obok szlachty ziemiańskiej ${ }^{9}$, mamy więc przykładnych księży ${ }^{10}$, wzorowych urzędników pracujących z poświęceniem dla dobra współobywateli ${ }^{11}$, sędziów znanych z bezstronności ${ }^{12}$ i uczonych, których życie i prace dostarczały dowodów, że szczera pobożność dobrze się godzi z doskonaleniem umysłu i naukowymi odkryciami ${ }^{13}$. Wśród zalet nieboszczyka przywiązanie do religii katolickiej z reguły wymieniane jest na pierwszym miejscu. Tak na przykład w mowie wygłoszonej 20 lutego 1810 r. w czasie obrządku pogrzebowego księcia Józefa Czartoryskiego biskup Jan Paweł Woronicz chwalił go przede wszystkim za „niezachwianą żadnymi nowościami staropolską prawowierność”, podkreślając dalej jego przywiązanie do wartości narodowych ${ }^{14}$. Z poselstwa zagranicznego Czartoryski „wrócił wreszcie do Ojczyzny nie cudzoziemcem, nie rozgorzałym obcych obyczajów miłośnikiem, nie wyśmiewaczem swego gniazda i rodu. Ocenił to, co tam dobrym i przydatnym dla swojej

${ }^{8}$ Obok cytowanego wyżej kazania na pogrzebie hrabiny Pociejowej na uwagę zasługują m.in.: J. Męciński, Kazanie podczas pogrzebowego obrzqdku Zofii z Romiszowskich hrabiny Moszyńskiéj w kościele krakouskim śu. Anny 6 października 1812 [b. m. r. dr.]; M. Łącki, Kazanie na pogrzebie... Katarzyny z hrabiów Dziatyńskich hrabiny Matachowskiej wojewodziny mazowieckiej, miane w Borkowicach dnia 12 grudnia 1814 roku, Radom [b. r. ]. W tym ostatnim kazaniu mowa jest o patriotyzmie nieboszczki, będącej bratową Stanisława Małachowskiego. Ród Małachowskich, przypominał kaznodzieja, wsławił się swą miłością Ojczyzny, Katarzyna była mu „w miłości Ojczyzny podobna".

${ }^{9}$ Ks. Dominik Łapiński, karmelita, w Kazaniu $w$ dzień pogrzebu Antoniego Skarbka Ważyńskiego podkomorzego oszmiańskiego, 30 czerwca 1813, Wilno [b. r. ], nakreślił modelowy portret wzorowego ziemianina, który w testamencie znaczną część majątku przeznaczył na modlitwy i jałmużny, a swym zacnym życiem dowiódł, że w każdym stanie można być cnotliwym wbrew rozpowszechnionemu mniemaniu, że ludziom majętnym trudno jest prowadzić życie prawdziwie chrześcijańskie.

${ }^{10}$ F. N. Golański (Kazanie... przy uroczystym przeniesieniu zwlok Daurida Pilchowskiego biskupa..., Wilno 1805) kładzie akcent na miłosierne uczynki biskupa wobec ubogich, chorych i więźniów. Karol Arendt (Kazanie podczas żatobnego nabożeństwa za ks. Marcina Krajewskiego proboszcza zambrowskiego, Warszawa 1809) podkreśla współdziałanie proboszcza $z$ władzami administracyjnymi i wpajanie parafianom posłuszeństwa wobec rządu, albowiem "religia i tron są na świecie najmocniejsze twierdze i tarcze naprzeciwko nierządom i zuchwalstwu czlowieka".

"Zob. Zbiór mów żałobnych na pogrzebie wielmożnego Seweryna Bończy Skarżyńskiego, radcy prefektury departamentu tomżyńskiego mianych $w$ Łonizy 1814 r., Łomża 1814.

${ }^{12}$ Zob. J. W. Eańcucki, Kazanie w czasie pogrzebu Mikolaja Urbańskiego, [b. m. ] 1805; zmarły był sędzią Trybunału Apelacyjnego Galicji Zachodniej.

13 Zob. A. Tomaszewski, Kazanie za duszęśp. ... ks. Marcina Odlanickiego Poczobuta, Wilno 1810. Jezuita Marcin Poczobutt-Odlanicki byl, jak wiadomo, profesorem astronomii Uniwersytetu w Wilnie, dokonał serii obserwacji planety Merkurego. Kaznodzieja Augustyn Tomaszewski był na tymże Uniwersytecie profesorem teologii i historii Kościoła.

${ }_{14}$ Motywy patriotyczne odgrywały stosunkowo niewielką rolę w ówczesnych kazaniach. Bliżej na ten temat: M. Hamanowa, Treści spoteczne $w$ kazaniach $z$ okresu Księstwa Warszawskiego, [w:] Historia, idee, polityka. Księga dedykowana Profesorowi Janowi Baszkiewiczowi, Warszawa 1995, s. 201-205. 
Ojczyzny znalazł, a pogardził tym, co się z dostojną powagą Polaka zgodzić nie mogło”. Dowodem jego patriotyzmu było dla kaznodziei polecenie w testamencie dwóm niezamężnym jeszcze córkom, by poślubiły Polaków ${ }^{15}$.

Osobną kategorię stanowią kazania wygłaszane z okazji śmierci ludzi najbardziej zasłużonych dla Ojczyzny, jak na przykład Tadeusz Czacki, lub zaliczanych do grona bohaterów narodowych, jak książę Józef Poniatowski ${ }^{16}$. Akcent położony był wówczas na motywy patriotyczne, na poświęcenie dla Ojczyzny, które to tematy poruszano w innych kazaniach na ogól rzadko i dyskretnie.

Pedagogika kazań pogrzebowych nie ogranicza się jednak do wpajania wiernym zasad przykładnego życia, lecz zmierza do nauczenia ich również sztuki dobrej śmierci, artis bene moriendi. Opowiada się zatem o ostatnich chwilach, jakie zmarli przeżyli pobożnie i wzorowo. Dobre uczynki tu na ziemi i ostatnie namaszczenie zapewniają im zbawienie i życie wiecz$\mathrm{ne}^{17}$. Śmierć nagła i niespodziewana bardziej jest gorzka, gdyż nie pozwala przygotować duszy na przyjęcie wieczności, i tylko ci, którzy mają czyste sumienie, nie obawiają się gwałtownego rozstania z życiem.

Pewność śmierci budzi nasz niepokój, który jest tym większy, że nie wiemy, kiedy i w jakich okolicznościach przyjdzie ona nas zabrać, a dołącza się tu jeszcze obawa zasłużonej kary. Wolimy więc zapomnieć o śmierci, nie myśleć i nie mówić o niej. Zważywszy jednak, że boimy się nie tyle samej śmierci, co tego, co czeka nas w życiu pozagrobowym, myśl o śmierci skłania nas do cnotliwego życia. Pijar Patrycy Przeczytański w kazaniu wygłoszonym w Dniu Zadusznym nawoływał wiernych: „Myślmy zatem o śmierci, bo ta myśl jest nam wielce pożyteczna" ${ }^{\prime 18}$. Aby móc spokojnie umrzeć, trzeba przede wszystkim przestać być nadmiernie przywiązanym do świata doczesnego. Kaznodzieje kierowali swe pouczenia w tej sprawie szczególnie do kobiet, ukazując im niebezpieczeństwa światowego życia, które nie pozwala przygotować się dobrze do życia wiecznego, i zachęcając je, by przedkładały religię nad modę i pobożność nad próżność.

Śmierć, którą człowiek przyjmuje bez oporu i bez lęku, zgadzając się z wolą Boską, jest piękna i słodka. Gdyby ludzie w krótkim swym życiu umieli przygotować się do śmierci, nie traktowaliby jej jako kary, lecz jako spełnienie słodkich wyroków niebios i godzinę nagrody ${ }^{19}$. Śmierć czlowieka cnotliwego, nawet najstraszliwsza, nie jest nieszczęściem, lecz początkiem wiecznej szczęśliwości. Wiara przynosi umierającemu pociechę, której rozum nie jest dać mu w stanie. Słabość ciała wzmaga siłę moralną wierzącego. Miłosierdzie Boskie towarzyszy

\footnotetext{
15 J. P. Woronicz, Mou'a w'czasie obrządku pogrzebowego... księcia Józefa Czartoryskiego...[20 lutego 1810], [w:] tenże, Pisma uybrane, opr. M. Nesteruk, Z. Rejman, Warszawa 1993, s. 452 i n.

${ }_{16}$ Tenże, Kazanie na pogrzebie sprou'adzonych do Warszawy zwtok śp.... Józefa Poniatowskiego...[10 września 1814], op. cit., s. 481 i n.

${ }_{17}$ Zob. B. Rok, Czlowiek wober śnierci w kulturze staropolskiej, Wrocław 1995, s. 110.

18 P. Przeczytański, Kazania przygodne i pogrzebowe... na różnych miejscach miane, t. 5, Warszawa 1822, s. 156.

19 Zob. Mou'a proboszcza Sulkońskiego na pogrzebie Seweryna Skarżyniskiego w Łomizy 2 sierpnia 1814, [w:] Zbiór mów żalobnych na pogrzebie wielmożnego Sewveryna Bończy Skarżyńskiego..., s. I.
} 
grzesznikowi nawet na jego łożu śmierci. Nawrócenie się heretyka lub niedowiarka, szczera skrucha grzesznika w ostatnich dniach życia zapewniają im śmierć pobożną i zbawienną.

Zauważyć trzeba, że ta pedagogika śmierci odwołuje się w większym stopniu do łagodnej perswazji niż do straszenia. Kaznodzieje więcej mówią o Boskim miłosierdziu niż o Bogu jako surowym sędzi. Zachęcają wiernych do cnotliwego życia raczej obietnicami wiecznej szczęśliwości niż groźbami wiecznego potępienia.

Od tej reguły bywały jednak wyjątki. Ksiądz Kawalewski głosił rychłe nadejście dnia Sądu Ostatecznego, o czym wnosił „z wielości fałszywych i chytrych proroków (...), co są odstępcy od wiary i Kościoła”, dalej „z rozruchów, wojen, głodu, powietrza”, a także spustoszenia miejsc świętych, którego doświadczamy. Sprawiedliwość Boska - głosił ks. Kawalewski skaże wszystkich grzeszników, a niedowiarków w szczególności, na wieczne męki piekielne. Dla potępionych nie będzie żadnego miłosierdzia i żadnej pociechy, cierpienia ich będą gorsze od wszystkiego, co ludzkie okrucieństwo może wymyślić tu na ziemi, i trwać będą bez końca. Kościól nie modli się za potępionych i nikt nie może pytać, „czyż podobna, aby Bóg nieskończenie dobry tak się miał srożyć całą wiecznością za krótko trwające występki?", ponieważ przemijające cnoty Bóg nagradza niebem także na wieczność ${ }^{20}$. Nie ma dobrej śmierci bez zacnego życia — podkreśla wielokrotnie ten kaznodzieja, który w jednym ze swych kazań wykrzykuje: „Niech umiera libertyn, deista, mason, żadnej wiary i religii w sobie nie mający - niewielka szkoda, bo on nawet niewart, że żyje. Niech umicra bezwstydny młodzik, na sprośne lubieżności wylany — niewielka szkoda, bo on sam szuka przyśpieszenia śmierci przez zbytek rozpusty, niech umiera próżniak (...), niech umiera niewstydliwa lubieżna niewiasta, [która jeśli] ustępuje ze świata, ustają zgorszenia zaraźliwsze nad samo powietrze" ${ }^{21}$. Na żal zasługują tylko ludzie pobożni i cnotliwi. Szczęściem dla wiernych były to poglądy raczej wyjątkowe, na ogół księża głoszący kazania wykazywali więcej miłosierdzia dla grzeszników.

Miłosierdzie to przejawiało się między innymi w częstych nawoływaniach do modlitwy za dusze przebywające w czyśćcu. Zmarli maja prawo do uroczystego pogrzebu, lecz to za mało. Chrześcijanie powinni wspomnieć ich przynajmniej raz do roku i modlitwą wspomagać ich dusze, cierpiące być może jeszcze w czyśćcu. Modlitwa taka to chrześcijański obowiązek, wypływający z poczucia sprawiedliwości i ludzkości, nie jest ona nigdy daremna, nawet jeśli dusza, za którą jest odmawiana, dostąpiła już zbawienia, a nawet jeśli została skazana na wieczne potępienie. Miłość bliźniego nie ogranicza się bowiem do świata doczesnego, nasi zmarli bracia oczekują od nas pomocy, wzywają nas, abyśmy wstawiali się za nimi do Boga. Nasze modlitwy moga przyspieszyć ich zbawienie. Dzień Zaduszny, poświęcony wspomnieniu zmarłych i modlitwie za nich, miał również swój aspekt pedagogiczny. W ka-

${ }^{20}$ K. Kawalewski, Kazanie na niedzielę II Adwentu, [w:] tenże, Rok I kazań niedzielnych..., Przemyśl 1814.

${ }^{21}$ Tenże, Kazanie przy pogrzebie NN: o życiu dobrym, cnotliwym, bogobojnym, które jest prosta droga do śmierci dobrej, a śmierć dobra jest bitym gościncem do życia przyszlego szczęstiwego, [w:] tenże, Rok III kazań różnych..., t. 4, Przemyśl 1816, s. 317 i n. 
zaniach, wygłaszanych tego dnia, księża przypominali wiernym o obowiązku dochowania w życiu zasad wiary chrześcijańskiej, aby zasłużyć sobie na niebo.

Rozważając sposób ujmowania problemu śmierci w kazaniach z interesującej nas doby, nie sposób nie wspomnieć o zagadnieniu śmierci bohaterskiej. Doba Księstwa Warszawskiego to wszak czas nieustannych wojen, kiedy młodzi mężczyźni wszystkich stanów i wszystkich klas społecznych umierają na polach bitew lub wskutek ran i trudów wojennych. Należałoby się więc spodziewać, że śmierć bohaterska zajmować będzie pierwszoplanowe miejsce w wygłaszanych wówczas kazaniach. W rzeczywistości - nic podobnego, problem ten sprawiał klerowi najwidoczniej ogromne trudności. Nawet w kazaniach patriotycznych, jak na przykład w kazaniu księdza Kazimierza Hoszkiewicza, wygłoszonym w Poznaniu 16 listopada 1806, w którym wzywał on do chwycenia za broń, by u boku Napoleona walczyć o wyzwolenie Polski, nie mówi się o oddaniu życia za Ojczyznę ${ }^{22}$.

Z podobnym problemem musiał borykać się benedyktyn ks. Paweł Szulczewski, wygłaszając w 1808 r. w Kościanie kazanie na nabożeństwie żałobnym „za poległych w sprawie Ojczyzny braci naszych Polaków" ${ }^{23}$. Po czternastu latach niewoli — mówił on do wiernych — wybiła godzina pomsty Boga nad ciemiężycielami i miłosierdzia dla uciemiężonych. Ręka Boga sprowadziła Napoleona, nadzieja zaś zmobilizowała Polaków do walki pod hasłem „Umrzyjmy lub bądźmy Polakami”. Prawo natury każe kochać Ojczyznę ponad wszystko. Człowiek boi się ran, kalectwa i śmierci, ale „dla miłości Ojczyzny życie nawet na ofiarę łożyć prawo natury pozwala”. Prawo to każe jej ofiarować majątek, życie własne i swego potomstwa. Kaznodzieja cytował testament hetmana Jana Zamoyskicgo: „Jeżeli w jakowym niebezpieczeństwie Rzplita potrzebować będzie pomocy, niechaj opiekunowie mego syna wyliczą dla niej sto tysięcy (...) gdyż miłość Ojczyzny nie kończy się ze śmiercią", wnet jednak powracał na bezpieczniejsze i wypróbowane ścieżki przypominając, że dobrym obywatelem może być tylko dobry chrześcijanin. To religia bowiem jest „źródłem szczęścia ludów i pomyślności narodów". Pytanie, czy złożenie swego życia w ofierze Ojczyźnie jest również zasługą przed Bogiem, pozostawało bez odpowiedzi.

Stwierdzić jednak trzeba, że problem śmierci bohaterskiej sprawiał ogromne trudności nie tylko polskim kaznodziejom, nie najlepiej radziła sobie z nim nawet znakomita skądinąd francuska propaganda napoleońska ${ }^{24}$. Śmierć na polu bitwy, brutalna i gwałtowna, nie dawała się wtloczyć w ramy odwiecznego i znajomego rytuału, który przynosił poczucie bezpieczeństwa umicrającemu, jego bliskim i rzeszy wiernych.

${ }^{22}$ Zob. K. Hoszkiewicz, Mowa patriotyczna miana do licznie zgromadzonych obywateli w" Poznanitu w kościele XX Dominikanów 16 listopada 1806 przez... plebana grodzieckiego, kanonika inflanckiego, czlonka Najwyższej Rady Narodowej w' r. 1794, Kalisz 1806.

${ }^{23}$ Zob. P. Szulczewski, Dwa kazania żalobne, Rawicz 1809.

${ }^{24}$ Zob. M. Senkowska-Gluck, Żý po Rewolucji, Wrocław 1994, s. 143 i nast. 